ORIGINAL ARTICLE

\title{
Does leucocytosis identify bacterial infections in febrile neonates presenting to the emergency department?
}

\author{
L Brown, T Shaw, W A Wittlake
}

Emerg Med J 2005;22:256-259. doi: 10.1136/emj.2003.010850

See end of article for authors' affiliations

.....................

Correspondence to: Dr L Brown, Department of Emergency Medicine, A108, Loma Linda University Medical Center and Children's Hospital, 11234 Anderson Street, Loma Linda, CA 92354, USA; LBROWNMD@AOL. com

Accepted for publication 23 February 2004
Objective: This study was undertaken to evaluate the discriminatory power of the peripheral white blood cell (WBC) count to identify bacterial infections in a cohort of febrile neonates ( $\leqslant 28$ days of age) presenting to an emergency department.

Methods: Retrospective medical record review using descriptive statistics and a receiver operating characteristic (ROC) curve. Neonates who presented to a tertiary care paediatric emergency department between 1 January 1999 and 22 August 2002, had a temperature $\geqslant 38^{\circ} \mathrm{C}$, underwent lumbar puncture, and had a WBC count obtained were included. They were divided according to microbiological and radiographic findings into four groups: bacterial infections, viral infections, pneumonia, and negative sepsis evaluations.

Results: A total of 69 febrile neonates met the inclusion criteria. The number of neonates in each group was as follows: 8 with bacterial infections, 10 with viral infections, 3 with pneumonias, and 48 with negative sepsis evaluations. There was substantial overlap in WBC counts among the groups. The area under the ROC curve was 0.7231 (95\% Cl 0.5665 to 0.8797 ).

Conclusion: In a cohort of febrile neonates evaluated in the emergency department, the WBC count had modest discriminatory power in identifying neonates with bacterial infections and demonstrated substantial overlap among groups. The present data suggest against the use of any WBC count threshold to identify bacterial infections in febrile neonates presenting to the emergency department.
T he difficulty in identifying sources of infection in febrile neonates $\leqslant 28$ days of age has been recognised for decades. ${ }^{1}$ Equally well recognised is that most febrile neonates do not harbour serious bacterial infections and probably would do well without any diagnostic testing or treatment. ${ }^{2-11}$ For the past decade, however, well publicised recommendations have suggested that all neonates with a temperature $\geqslant 38^{\circ} \mathrm{C}$ undergo a diagnostic evaluation including a full blood count, urinalysis, lumbar puncture with cerebrospinal fluid (CSF) analysis and bacterial culture, receive parenteral antibiotics (typically ampicillin and cefotaxime), and be admitted to the hospital. ${ }^{12}{ }^{13}$ Although the risk posed to a neonate with an untreated bacterial infection is substantial, the process of the "septic workup" is not undertaken without exposing the infant to other risks such as nosocomial infections and medication errors. ${ }^{14}$ Unfortunately, identifying bacterial infections typically requires awaiting culture results and occurs long after the neonate has left the emergency department (ED).

The idea of a simple, readily available, inexpensive diagnostic test that yields results within an hour and accurately identifies bacterial infections in febrile neonates is alluring. If such a test was available, these febrile neonates would likely benefit from immediate parenteral antibiotic therapy whereas those with a negative test could forego antibiotics and, if other discharge criteria were met, perhaps even be discharged. A potential candidate for such a diagnostic test is the peripheral white blood cell (WBC) count. The WBC count is familiar to emergency physicians, simple, readily available, yields prompt results, and is inexpensive. The use of WBC count thresholds has been widely advocated to risk stratify febrile children. ${ }^{2} 35$ 7-9 1213 The use of the WBC count to identify bacterial infections in febrile neonates, however, remains unexplored. ${ }^{15}$

The objective of this study was to evaluate the discriminatory power of the WBC count to identify bacterial infections in a cohort of febrile neonates who presented to our ED.

\section{METHODS}

We retrospectively reviewed the medical records of all neonates $\leqslant 28$ days of age who presented to our tertiary care paediatric ED between 1 January 1999 and 22 August 2002 and underwent lumbar puncture during the index visit. An initial screening of all medical records was undertaken to exclude those neonates for whom the medical record was unavailable, no ED triage temperature was recorded, or the ED triage temperature was $<38^{\circ} \mathrm{C}$. A trained data abstractor then used a standardised data collection form and recorded the following study variables for the remaining neonates: date of birth, date of visit, ED triage temperature, initial WBC count, blood culture results, CSF white and red blood cell counts, CSF culture and bacterial antigen study results, viral study results (including but not limited to respiratory syncytial virus (RSV), rotavirus, enterovirus, and herpes simplex virus), urinalysis and urine culture results, stool culture results, and the radiologist's final interpretation of a chest $x$ ray if taken. Age was calculated electronically from the date of birth and date of visit. Subjects were to be subsequently excluded if no WBC count had been done in the ED.

We divided the neonates on the basis of the microbiological and radiographic data into four groups:

- those with bacterial infections-that is, positive cultures of blood, urine, CSF, or stool or a clinical diagnosis of cellulitis, fasciitis, omphalitis, osteomyelitis, or mastitis

- those with viral infections - that is, positive viral culture, polymerase chain reaction, or immunofluorescence study

- those with radiographic evidence of pneumonia-that is, infiltrate on chest $x$ ray without meeting the criteria for the bacterial or viral group 
- those with no positive findings ("negative sepsis evaluation").

Statistical analyses included descriptive statistics and the generation of a receiver operating characteristic (ROC) curve. Our data were not normally distributed so we have presented these as medians and interquartile ranges (IQRs). Statistical analyses were performed using Stata 8 (STATA Corporation, College Station, TX). Our institutional review board responsible for monitoring human subject research approved the study.

\section{RESULTS}

We identified 206 neonates $\leqslant 28$ days of age who had been seen in our ED and had undergone lumbar puncture during the study period. Medical records were available for all neonates and they all had an ED triage temperature recorded. A total of 135 neonates had ED triage temperatures $<38^{\circ} \mathrm{C}$. Of the remaining 71, two did not have a WBC count done while in the ED. Our main study group consisted of the remaining 69 (31 girls $(45 \%)$ ) neonates. The age, temperature, and WBC counts of these 69 neonates were tabulated. The median age was 17 days (IQR 10-22; range 2-28). The median temperature was $38.4^{\circ} \mathrm{C}\left(\mathrm{IQR} 38.2-38.8^{\circ} \mathrm{C}\right.$; range $\left.38.0-39.9^{\circ} \mathrm{C}\right)$. The median WBC count was $11.9 \times 10^{9}$ cells/l (IQR 9.8$15.0 \times 10^{9}$ cells/l; range $4.3-27.0 \times 10^{9}$ cells/l) .

Eight neonates ( $12 \%$; two girls) had bacterial infections. Four neonates, aged 15, 16, 17, and 17 days, had urinary tract infections (three had Escherichia coli and one had enterococcus) and their temperatures ranged from $38.4{ }^{\circ} \mathrm{C}$ to $38.6^{\circ} \mathrm{C}$. Two infants aged 4 and 12 days had bacteraemia (one E. coli and one group B streptococcus) with temperatures of $38.2{ }^{\circ} \mathrm{C}$ and $38.8^{\circ} \mathrm{C}$, respectively. A 20 day old neonate with an ED temperature of $38.2^{\circ} \mathrm{C}$ was diagnosed as having Salmonella meningitis and a brain abscess. It appeared from the medical record that this infant did not have stool studies performed. One 11 day old neonate with a temperature of $38.7^{\circ} \mathrm{C}$ had a relatively confusing picture. The family initially refused lumbar puncture and antibiotics were administered. On the second day of hospitalisation, the family consented to a lumbar puncture which revealed 12618 white blood cells and 109 red blood cells $/ \mathrm{mm}^{3}$. Subsequent CSF culture, viral polymerase chain reaction testing for herpes simplex virus, and bacterial antigen tests were all negative. This infant's urine culture revealed 50000-100000 colony forming units/ $\mathrm{ml}$ of mixed $E$. coli and enterococcus.

We identified viral infections in 10 infants (three girls). RSV was identified in the nasopharyngeal secretions of six infants aged 13, 17, 21, 25, 27, and 27 days whose temperatures ranged from $38.0^{\circ} \mathrm{C}$ to $38.9^{\circ} \mathrm{C}$. One 19 day old infant with a temperature of $38.2^{\circ} \mathrm{C}$ had rotavirus in stool and three infants aged 9,14 , and 26 days with temperatures of $39.9^{\circ} \mathrm{C}, 38.8^{\circ} \mathrm{C}$, and $38.6^{\circ} \mathrm{C}$, respectively, had enterovirus (two

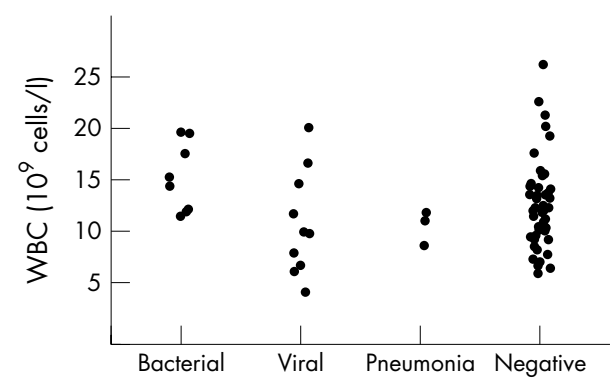

Figure 1 Distribution of white blood cell (WBC) counts by microbiological/radiographic group.

\begin{tabular}{|c|c|c|}
\hline $\begin{array}{l}\text { WBC count } \\
\left(10^{9} \text { cells } / \mathrm{I}\right)\end{array}$ & $\begin{array}{l}\text { Bacterial infection } \\
\text { identified }\end{array}$ & $\begin{array}{l}\text { No bacterial } \\
\text { infection identified }\end{array}$ \\
\hline$<10$ & 0 & 18 \\
\hline $10-12$ & 2 & 14 \\
\hline $12.1-15$ & 2 & 13 \\
\hline $15.1-17$ & 1 & 7 \\
\hline $17.1-20$ & 3 & 2 \\
\hline$>20$ & 0 & 4 \\
\hline
\end{tabular}

cases identified in the CSF and one in the nares and conjunctiva). There was no case of herpes simplex virus.

Three neonates were diagnosed as having pneumonia. One 4 day old boy demonstrated a temperature of $38.2^{\circ} \mathrm{C}$ and a non-specific hazy opacity of the right lung. A 12 day old boy had a temperature of $38.0^{\circ} \mathrm{C}$ and a right lower lobe patchy infiltrate. A 3 day old girl with a temperature of $38.8^{\circ} \mathrm{C}$ had bilateral opacities at the lung bases. None of these neonates with radiographic pneumonia had documented bacteraemia or RSV.

The remaining 48 (26 girls $(54 \%))$ neonates were categorised in the negative sepsis evaluation group. This group had a median age of 17.5 days (IQR 7.5-22; range 2-28) and a median temperature of $38.4^{\circ} \mathrm{C}$ (IQR $38.2-38.8^{\circ} \mathrm{C}$; range $38.0-39.8^{\circ} \mathrm{C}$ ). All 69 neonates were admitted to the hospital and 68 (99\%) received parenteral antibiotics. All were subsequently discharged in good condition.

The WBC counts for neonates with bacterial infections, viral infections, pneumonia, and negative sepsis evaluations had substantial overlap among the groups (fig 1). Given the difficulties in differentiating bacterial from viral pneumonia by radiographic appearance, ${ }^{16}$ the three neonates with pneumonia were excluded from the remaining analyses. Of the remaining 66 neonates, the eight neonates with bacterial infections had WBC counts ranging from $11.0 \times 10^{9}$ cells $/ 1$ to $19.9 \times 10^{9}$ cells/l (table 1). The highest positive likelihood ratio occured when a threshold of $17 \times 10^{9}$ cells/ 1 was chosen (table 2). Febrile neonates in our study with WBC counts $\geqslant 17 \times 10^{9}$ cells $/ 1$ were 3.8 times more likely to have a bacterial infection than those with lower WBC counts. At this threshold the WBC was 38\% sensitive (95\% confidence interval (CI) $9 \%$ to $76 \%$ ) in detecting bacterial infections. The highest threshold at which the WBC count retained 100\% sensitivity was $10 \times 10^{9}$ cells $/ 1$. At this threshold, the specificity was $31 \%$ (95\% CI $20 \%$ to $45 \%$ ). The area under the ROC curve was 0.7231 (95\% CI 0.5665 to 0.8797 ) representing moderate discriminatory power (fig 2). ${ }^{17}$

\begin{tabular}{|c|c|c|c|c|c|c|}
\hline $\begin{array}{l}\text { WBC } \\
\text { threshold } \\
\text { (109 cells/l) }\end{array}$ & $\begin{array}{l}\text { Sensitivity } \\
\text { (\%) }\end{array}$ & $\begin{array}{l}\text { Specificity } \\
(\%)\end{array}$ & PPV $^{*}(\%)$ & $\mathrm{NPV}^{*}(\%)$ & $\mathbf{L R +}$ & $\mathbf{L R}$ \\
\hline 5 & 100 & 2 & 12 & 100 & 1.0 & 0.0 \\
\hline 10 & 100 & 31 & 17 & 100 & 1.4 & 0.0 \\
\hline 12 & 75 & 53 & 18 & 94 & 1.6 & 0.5 \\
\hline 15 & 50 & 74 & 21 & 91 & 1.9 & 0.7 \\
\hline 17 & 38 & 89 & 33 & 91 & 3.8 & 0.7 \\
\hline 20 & 0 & 93 & 0 & 87 & 0.0 & 1.1 \\
\hline 22 & 0 & 97 & 0 & 88 & 0.0 & 1.0 \\
\hline 25 & 0 & 98 & 0 & 88 & 0.0 & 1.0 \\
\hline
\end{tabular}

*The prevalence of bacterial infections in our study population was $12 \%$. Neonates classified as having pneumonia were excluded from this analysis. $L R+$, likelihood ratio for a positive test; LR-, likelihood ratio for a negative test; NPV, negative predictive value; PPV, positive predictive value. 


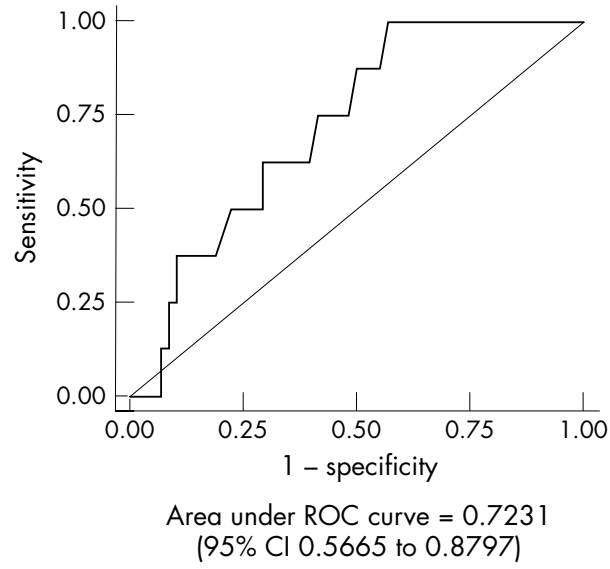

Figure 2 Receiver operating characteristic (ROC) curve for white blood cells (WBCs) predicting bacterial infections.

\section{DISCUSSION}

The WBC count demonstrated moderate discriminatory power for identifying febrile neonates with bacterial infections in our study population. We were unable to identify an appropriate, clinically useful threshold value that differentiated febrile neonates with bacterial infections from other febrile neonates in the ED. Although a WBC count threshold of $17 \times 10^{9}$ cells/ 1 yields a positive likelihood ratio of 3.8 , nearly two thirds $(62 \%)$ of febrile neonates with bacterial infections would not be identified using this threshold because the sensitivity is only $38 \%$ at this threshold.

Prior studies have examined the utility of the WBC count for evaluating young febrile infants. The applicability of these studies to the clinical practice of evaluating febrile neonates in the ED, however, is problematic. These studies are occasionally from decades ago and included only neonates still in the hospital following delivery ${ }^{18-20}$ or infants older than one month of age, ${ }^{21021-25}$ or used a specific WBC count range as a component of the inclusion criteria for the study. ${ }^{35} 8$

One interesting feature of the test characteristics of the WBC count in febrile neonates in our study is the presence of $100 \%$ negative predictive value for WBC counts $<10 \times 10^{9}$ cells/l. No febrile neonate with a bacterial infection had a WBC count $<10 \times 10^{9}$ cells/l; $18 / 69$ (26\%) febrile neonates had a WBC count $<10 \times 10^{9}$ cells/l. Only one infant in our study demonstrated any degree of neutropenia with a WBC count of $4.3 \times 10^{9}$ cells/l. Rather than focusing on identifying bacterial infections, future studies could be directed towards examining the potential use of the negative predictive value of the WBC count to identify a subset of neonates for whom it is appropriate to withhold antibiotics or discharge. This may be especially helpful in conjunction with rapid viral testing that is becoming increasingly available in the ED. ${ }^{26}$

Our study has limitations. The retrospective study design did not allow for the study of the presence of ill appearance, a feature commonly used to risk stratify febrile children. ${ }^{2}{ }^{12}$ We used the performance of a lumbar puncture as an inclusion criterion. We selected this procedure because we wanted to include only those febrile neonates for whom the most complete set of microbiological data was available. This may have led to a selection bias towards sicker neonates. Although we have no practice guidelines regarding the care of febrile neonates in our ED, our experience suggests that a "septic workup" is always or nearly always performed on febrile neonates presenting to our ED. Although the presence of immature neutrophils has been suggested to be associated with bacterial infections in children, ${ }^{2} 5618$ we elected not to study these-that is, "bands". The reproducibility of the "band count" or "left shift" has been sufficiently challenged to suggest against the use of immature neutrophils in clinical decision making. ${ }^{27}{ }^{28}$ Our modest sample size resulted in a wide 95\% confidence interval for the area under the ROC curve. A larger study would yield a more accurate estimation of the true area under the ROC curve.

\section{SUMMARY AND CONCLUSION}

In a sample of febrile neonates evaluated in our ED, the WBC count had only modest discriminatory power in identifying neonates with bacterial infections and demonstrated substantial overlap among groups. Although it is an intuitively appealing possibility that a test as simple as a WBC count would identify bacterial infections in febrile neonates, our data suggest against the use of any WBC count threshold to identify bacterial illnesses in febrile neonates presenting to the ED.

\section{ACKNOWLEDGEMENT}

We would like to thank Madison Brown for her assistance in the preparation of this manuscript.

\section{Authors' affiliations}

L Brown, T Shaw, W A Wittlake, Department of Emergency Medicine, Loma Linda University Medical Center and Children's Hospital, Loma Linda, California, USA

Competing interests: none declared

\section{REFERENCES}

1 Silverman WA, Homan WE. Sepsis of obscure origin in the newborn. Pediatrics 1949:3:157-76.

2 Jaskiewicz JA, McCarthy CA, Richardson AC, et al. Febrile infants at low risk for serious bacterial illness: an appraisal of the Rochester criteria and implications for management. Pediatrics 1994;94:390-6.

3 McCarthy CA, Powell KR, Jaskiewicz JA, et al. Outpatient management of selected infants younger than two months of age evaluated for possible sepsis. Pediatr Infect Dis J 1990;9:385-9.

4 Baker MD, Bell LM. Unpredictability of serious bacterial illness in febrile infants from birth to 1 month of age. Arch Pediatr Adolesc Med 1999;153:508-11.

5 Chiu $\mathrm{CH}$, Lin TY, Bullard MJ. Identification of febrile neonates unlikely to have bacterial infections. Pediatr Infect Dis J 1997;16:59-63.

6 Ferrera PC, Bartfield JM, Snyder HS. Neonatal fever: utility of the Rochester criteria in determining low risk for serious bacterial infections. Am J Emerg Med 1997; 15:299-302.

7 Kadish HA, Loveridge B, Tobey J, et al. Applying outpatient protocols in febrile infants 1-28 days of age: can the threshold be lowered? Clin Pediatr (Phila) 2000;39:81-8

8 Chiv CH, Lin TY, Bullard MJ. Application of criteria identifying febrile outpatient neonates at low risk for bacterial infections. Pediatr Infect Dis J 1994; 13:946-9.

9 Dagan R, Sofer S, Phillip M, et al. Ambulatory care of febrile infants younger than 2 months of age classified as being at low risk for having serious bacterial infections. J Pediatr 1988;1 12:355-60.

10 Greene JW, Hara C, O'Connor S, et al. Management of febrile outpatient neonates. Clin Pediatr 1981;20:375-80

11 DeAngelis $C$, Joffe A, Willis $E$, et al. Hospitalization $v$ outpatient treatment of young, febrile infants. Am J Dis Child 1983;137:1150-2.

12 Baraff L, Bass JW, Fleisher GR, et al. Practice guideline for the management of infants and children 0 to 36 months of age with fever without a source. Pediatrics 1993;92:1-12.

13 Steere M, Sharieff GQ, Stenklyft PH. Fever in children less than 36 months of age-Questions and strategies for management in the emergency department. J Emerg Med 2003;25:149-57.

14 DeAngelis $C$, Joffe $A$, Wilson $M$, et al. latrogenic risks and financial costs of hospitalizing febrile infants. Am J Dis Child 1983;137:1146-9.

15 Malik A, Hui CP, Pennie RA, et al. Beyond the complete blood cell count and creactive protein: A systematic review of modern diagnostic tests for neonatal sepsis. Arch Pediatr Adolesc Med 2003;157:51 1-16.

16 Kramer MS Roberts-Braver R, Williams RL. Bias and "overcall" in interpreting chest radiographs in young febrile children. Pediatrics 1992;90: 11-13.

17 Swets JA. Measuring the accuracy of diagnostic systems. Science 1988;240:1285-93.

18 Spector SA, Ticknor W, Grossman M. Study of usefulness of clinical and hematologic findings in the diagnosis of neonatal bacterial infections. Clin Pediatr 1981;20:385-92.

19 Voora S, Srinivasan G, Lilien LD, et al. Fever in full-term newborns in the first four days of life. Pediatrics 1982;69:40-4. 
20 Albers WH, Tyler CW, Boxerbaum B. Asymptomatic bacteremia in the newborn infant. J Pediatr 1966;69:193-7.

21 Baker MD, Bell LM, Avner JR. Outpatient management without antibiotics of fever in selected infants. New Engl J Med 1993;329:1437-41.

22 Bachur RG, Harper MB. Predictive model for serious bacterial infections among infants younger than 3 months of age. Pediatrics 2001;108:311-16

23 Baskin MN, O'Rourke EJ, Fleisher GR. Outpatient treatment of febrile infants 28 to 89 days of age with intramuscular administration of ceftriaxone. J Pediatr 1992;120:22-7.

24 Baker MD, Bell LM, Avner JR. The efficacy of routine outpatient management without antibiotics of fever in selected infants. Pediatrics 1999;103:627-31.
25 Bonsu BK, Harper MB. Identifying febrile young infants with bacteremia: Is the peripheral white blood cell count an accurate screen? Ann Emerg Med 2003;42:216-25.

26 Titus MO, Wright SW. Prevalence of serious bacterial infections in febrile infants with respiratory syncytial virus infection. Pediatrics 2003;1 12:282-4.

27 Luxmore B, Powell KR, Diaz SR, et al. Absolute band counts in febrile infants: Know your laboratory. Pediatrics. 2002;110: el2, Full article available at:http://www.pediatrics.org/cgi/content/full/110/1/e12 (accessed 11 August 2003).

28 Kuperman N, Walton EA. Immature neutrophils in the blood smears of young febrile children. Arch Pediatr Adolesc Med 1999;153:261-6. 